\title{
Effects of comprehensive smoke-free legislation in Europe
}

Lucia Maria Lotrean, MD. ${ }^{(1)}$

\begin{abstract}
Lotrean LM.
Effects of comprehensive smoke-free legislation in Europe. Salud Publica Mex 2008;50 suppl 3:S292-S298.
\end{abstract}

\begin{abstract}
This paper reviews data regarding the effects of the legislation banning smoking in enclosed public places, including workplaces, restaurants and bars which entered into force in several countries of Europe starting with the year 2004. The source of data is represented by articles and short information published in peer reviewed journals or in electronic format between the years 2005 and 2008. Highlights include a consideration of the effects of these laws on the attitudes of the population regarding their implementation, exposure to passive smoking in public places as well as the scientific evidence on the public health and economic impact of these laws. The results of smoking ban in public places observed in several parts of Europe support initiatives in many countries toward implementing smoke-free legislation, particularly those who have ratified the Framework Convention on Tobacco Control, which calls for legislation to reduce tobacco smoke pollution.
\end{abstract}

Key words: second hand smoke; legislation; Europe

\author{
Lotrean LM. \\ Efectos de la legislación antitabaco en Europa. \\ Salud Publica Mex 2008;50 supl 3:292-S298.
}

\section{Resumen}

Se revisaron datos sobre el impacto de las leyes que prohíben fumar en espacios públicos cerrados, incluyendo centros de trabajo, restaurantes y bares, las cuales entraron en vigor en varios países de Europa en 2004. La fuente de datos incluye artículos indexados y notas breves publicadas en revistas científicas o en formato electrónico entre 2005 y 2008. Los hallazgos incluyen una descripción del impacto de estas leyes sobre las actitudes de la población con respecto a su implementación, la exposición al humo de tabaco ambiental en espacios públicos cerrados, así como la evidencia científica sobre el impacto de estas leyes en la salud pública y en la economía. Los resultados de la prohibición de fumar en lugares públicos que se observaron en varios países de Europa confirman la importancia de promulgar iniciativas legislativas para crear ambientes libres de humo de tabaco en varios países del mundo, en particular en aquellos que han ratificado en Convenio Marco para el Control del Tabaco, que promueve una legislación para reducir la contaminación del aire con humo de tabaco.

Palabras clave: humo de tabaco ambiental; legislación; Europa

(I) Department of Environmental Health, University of Medicine and Pharmacy, Cluj-Napoca, Romania

Accepted on: April 28, 2008

Address reprint requests to: Lucia Maria Lotrean, Department of Environmental Health, University of Medicine and Pharmacy,

Cluj-Napoca, Romania. Primaverii 6/I66, Cluj-Napoca, Romania

E-mail: llotrean@umfcluj.ro 
Second-hand smoke (SHS), sometimes referred to Sas passive smoking carries serious health risks, especially for children and those who are chronically and regularly exposed. It has been scientifically proven that exposure to tobacco smoke cause death, disease and disability. ${ }^{1,2}$ Hence, in order to protect the health of non-smokers, laws banning smoking in enclosed public places, including workplaces, restaurants and bars entered into force in several municipalities, states or countries from all over the world in the last years.

In March 2004 Ireland became the first European country to institute an outright ban on smoking in the workplace, including the country's more than 10000 pubs. Several other countries from Europe stepped into the same line few months later: Norway (2004), Malta (2004), Italy (2005), Sweden (2005). ${ }^{3}$ Smoking in public places in Italy, Malta and Sweden must be in separate ventilated smoking rooms. In reality this means there are relatively few enclosed public places where smokers can light up, but they exist. In Italy for instance, because of the high cost due to the tight standards on air quality defined by the smoking ban, less than $1 \%$ of the hospitality premises from Northern Italy reported that they had built smoking areas in their venues. ${ }^{4}$

Scotland ban smoking in all enclosed public places in 2006, while the year 2007 brought comprehensive smoking ban laws in several parts of United Kingdom (England, Wales, Northern Ireland), France, Finland and Estonia. $^{3}$

In the present, many countries of Europe restrict smoking in different public places, but there are several exceptions, such as hospitality industry. The evidence based effects from the country which already adopted comprehensive smoking ban laws, could help the efforts of spreading these laws in Europe and other parts of the world.

Hence, the aim of this study is to review the studies conducted in order to evaluate the impact of the complete ban on smoking in enclosed public places in different countries of Europe. These will offer important data for advocates and public health professionals in their activity of support for the implementation of tobacco free laws.

\section{Material and Methods}

This paper reviews data regarding the effect of the clean indoor air laws implemented in Europe. The source of data is represented by articles and short information published in peer reviewed journals or in electronic format between the years 2005 and 2008. Highlights include a consideration of the effects of these laws on the attitudes of the population regarding their implementation, exposure to passive smoking in public places as well as the scientific evidence on the public health and economic impact of these laws.

\section{Compliance with the comprehensive smoking ban}

To ensure the success of clean indoor air policies, high levels of compliance must be achieved and maintained. ${ }^{2}$ Several information regarding the level of compliance with the law can be obtained from data collected from observational studies of workplaces and hospitality venues as well as from investigating population' perception on the compliance with the low and self-reported exposure to SHS in bars, restaurants, and workplaces. Information about the quality of the indoor air and about salivary and urinary cotinine levels among different categories of population can offer also valuable information. Enforcement and compliance data collected by the state authorities mandated with this task are also important.

In several countries from Europe, both direct studies in hospitality venues, 5,6 and surveys among population ${ }^{7}$ showed a good compliance with the law, especially in the hospitality venues. In Italy, almost $90 \%$ of the population had the perception that the smoking bans were observed in bars and restaurants, and 70\% in the workplace, including small workplaces. ${ }^{7}$ Among the owners of 1641 hospitality premises from Italy, 92\% reported that all customers respected the ban; only $11 \%$ had had to ask customers to stop smoking. ${ }^{4}$

Studies from Italy, Ireland and Scotland also showed important changes in exposure to second hand smoke, ${ }^{4,8,9}$ as it will be exemplified in more detail further in this article.

The checks performed by the police and other civil forces in Italy also showed good compliance with the law in hospitality premises; out of about 6000 checks only $100(1.5 \%)$ violations were observed. ${ }^{4}$ In Ireland, six months after the legislation was introduced a survey carried out by the Office of Tobacco Control reporting on 26627 inspections showed compliance levels of $94 \%$. Data from the free phone compliance line, which facilitated the publicin notifying breaches of the legislation also indicate theease with which the legislation has been implemented and enforced. In the six month period of the report, 2555 calls were made to the compliance line, peaking in the first month at 1524 and thereafter showing a downward trend to 145 complaints recorded in September 2004. ${ }^{10}$ 


\section{Attitudes regarding comprehensive smoking ban}

Public support for the clean indoor laws is vital to its long-term success. Support will depend on the public's experience with the law, awareness of the health risks associated with SHS, and the public's understanding of the relative costs and benefits of the law. ${ }^{2}$

In Ireland, a study evaluated the support for, and perceptions of, the impacts of smoke-free workplace legislation among bar workers from three regions of Ireland, before the implementation of the law and one year later. The results showed that in the pre-implementation phase $59.5 \%$ of participants supported the legislation, increasing to $76.8 \%$ post-implementation. Support increased among smokers by 27.3 percentage points from $39.4 \%$ to $66.7 \%(p<0.001)$ and among non-smokers by $12.4 \%$ percentage points from $68.8 \%$ to $81.2 \%(p=0.003)$. However, negative perceptions also increased, particularly for perceptions that the legislation has a negative impact on business (from $50.9 \%$ to $62.7 \%, p=0.008$ ) and that fewer people would visit pubs ( $41.8 \%$ to $62.7 \%, p<0.001$ ). Despite of these concerns, pre-legislation three-quarters of participants agreed that the legislation would make bars more comfortable and was needed to protect workers' health. Post-legislation these proportions increased to over $90 \%(p<0.001) .{ }^{11}$

Another study investigated the attitudes regarding the clean indoor law of a national representative sample of adult smokers from Ireland, surveyed before the implementation of the law and 8-9 months after its implementation. Support for total bans among Irish smokers increased in all venues, including workplaces ( $43 \%$ to $67 \%$ ), restaurants ( $45 \%$ to $77 \%$ ), and bars/pubs (13\% to $46 \%$ ). Overall, $83 \%$ of Irish smokers reported that the smoke-free law was a "good" or "very good" thing. ${ }^{12}$

Moreover, the impact that it has had on the Irish population was very well captured on a programme which was broadcast on national television on New Years Day 2005. Market research carried out for the programme "2004: How was it for you" found that from a list of 30 positive events that happened in Ireland in 2004, including many memorable international sporting achievements, the implementation of the smoke-free initiative in all workplaces topped the poll. Not only did it top the poll, it was a clear $15 \%$ ahead of the second placed event, Ireland's only Olympic Games gold medal winner in 2004. ${ }^{10}$

In Scotland, before the implementation of the law, many bar workers from 72 bars from several Scottish cities and rural areas agreed with the proposed legislation on smoking (69\%) and the need for it to protect the health of workers (80\%). Moreover, after the implementation of the law, a significant positive attitudinal change towards the legislation was seen. Post-implementation, support for the legislation rose to $79 \%$, bar workers continued to believe it was needed to protect health $(81 \%)$. Initial acceptance was greater among younger bar workers; older workers, initially more sceptical, became less so with experience of the legislation's effects. ${ }^{13}$

In Italy, after the implementation of the law, $90.4 \%$ of a national representative sample of adult population were moderately to strongly in favor of smoke-free areas in public places such as cafes and restaurants and $86.8 \%$ supported the total ban of smoking in all workplaces, public and private. ${ }^{7}$

\section{Changes in exposure to SHS}

In Ireland, a study measured the concentrations of particulate matter $2.5 \mu \mathrm{m}$ or smaller $\left(\mathrm{PM}_{2.5}\right)$ in 42 pubs from Dublin before and after the ban; benzene concentrations were also measured in 26 of the pubs. The results showed that an $83 \%$ reduction in $\mathrm{PM}_{2.5}$ and an $80.2 \%$ reduction in benzene concentration in the pubs. ${ }^{8}$

The levels of $\mathrm{PM}_{2.5}$ in 41 pubs from 2 Scottish cities also decreased two months after the implementation of the law from before averaged $246 \mu \mathrm{g} / \mathrm{m}^{3}$ (range 8-902 $\mu \mathrm{g} / \mathrm{m}^{3}$ ) to average level reduced to $20 \mu \mathrm{g} / \mathrm{m}^{3}$ (range 6-104 $\left.\mu \mathrm{g} / \mathrm{m}^{3}\right)$ in the period after the ban. Actually, $\mathrm{PM}_{2.5}$ concentrations in most pubs post-ban were comparable to the outside ambient air $\mathrm{PM}_{2.5}$ level. ${ }^{14}$

Bar workers from 72 bars of several Scottish cities and rural areas self reported a decrease in duration of their workplace exposure to SHS within the last seven days from of $28.5 \mathrm{~h}$ before the legislation to $0.83 \mathrm{~h}$ one year after the implementation of the law. Moreover, a reduction in non-smokers' salivary cotinine levels of $89 \%$ (95\% confidence interval $85-92 \%$ ) was observed. ${ }^{9}$

Implementation of Scotland's smoke-free legislation has been accompanied within one year by a large reduction in exposure to secondhand smoke among the adult non-smokers from which has been greatest in non-smokers living in non-smoking households. Overall, geometric mean cotinine concentrations in adult non-smokers fell by 39\% (95\% confidence interval 29\% to $47 \%$ ), from $0.43 \mathrm{ng} / \mathrm{ml}$ at baseline to $0.26 \mathrm{ng} / \mathrm{ml}$ after legislation $(p<0.001)$. In non-smokers from non-smoking households, geometric mean cotinine concentrations fell by $49 \%$ ( $40 \%$ to $56 \%$ ), from $0.35 \mathrm{ng} / \mathrm{ml}$ to $0.18 \mathrm{ng} / \mathrm{ml}$ $(p<0.001)$. The $16 \%$ fall in cotinine concentrations in nonsmokers from smoking households was not statistically significant. A decrease in the reported exposure to SHS in public places (pubs, other workplaces, and public transport), but not in homes and cars, was observed, 
while no evidence of displacement of smoking from public places into the home was found. ${ }^{15}$

The Scottish smoke-free legislation has reduced exposure to secondhand smoke among children in Scotland, too, particularly among groups with lower exposure in the home. The geometric mean salivary cotinine concentration in non-smoking children fell from $0.36(95 \%$ confidence interval 0.32 to 0.40$) \mathrm{ng} / \mathrm{ml}$ to 0.22 $(0.19$ to 0.25$) \mathrm{ng} / \mathrm{ml}$ after the introduction of smoke-free legislation in Scotland -a 39\% reduction. The extent of the fall in cotinine concentration varied according to the number of parent figures in the home who smoked but was statistically significant only among pupils living in households in which neither parent figure smoked $(51 \%$ fall, from 0.14 (0.13 to 0.16$) \mathrm{ng} / \mathrm{ml}$ to 0.07 (0.06 to 0.08 ) $\mathrm{ng} / \mathrm{ml}$ ) and among pupils living in households in which only the father figure smoked ( $44 \%$ fall, from $0.57(0.47$ to 0.70$) \mathrm{ng} / \mathrm{ml}$ to 0.32 ( 0.25 to 0.42$) \mathrm{ng} / \mathrm{ml}$ ). Little change occurred in reported exposure to SHS in childrens' own homes or in cars, but a small decrease in exposure in other people's homes was reported. Children reported lower exposure in cafes and restaurants and in public transport after legislation. ${ }^{16}$

In Italy, a study performed in 40 hospitality venues from Rome showed that the application of the smoking ban led to a considerable reduction in the exposure to indoor fine particles (from a mean concentration of 119.3 microg $/ \mathrm{m}^{3}$ before the ban to $38.2 \mathrm{microg} / \mathrm{m}^{3}$ after three months $(p<0.005)$, and then to $43.3 \mathrm{microg} / \mathrm{m}^{3}$ a year later $(p<0.01)$ ) as well as ultrafine particles (from 76956 particles $/ \mathrm{cm}^{3}$ to 38079 particles $/ \mathrm{cm}^{3}(p<0.0001)$ and then to 51692 particles $/ \mathrm{cm}^{3}(\mathrm{p}<0.01)$. These data were confirmed by a reduction of urinary cotinine among non-smoking workers (from $17.8 \mathrm{ng} / \mathrm{ml}$ to $5.5 \mathrm{ng} / \mathrm{ml}, p<0.0001$ and then to $3.7 \mathrm{ng} / \mathrm{ml}, p<0.0001){ }^{17}$

Other studies from Italy measured environmental nicotine concentrations in four pubs and three discos in Florence and concentrations of $\mathrm{PM}_{2.5}$ in two restaurants and two pubs in Milan and in six bars in Trieste before and after the smoking ban, showing reductions ranging from 70 to $97 \%{ }^{4}$

\section{Effects on active smoking of comprehensive smoking ban}

In addition to protecting nonsmokers from exposure to tobacco smoke, these policies have the potential to reduce cigarette smoking both by encouraging adult smokers to quit smoking and preventing youth from initiating smoking. These reductions result, in part, from the strengthening of social norms against smoking that follows the adoption of these policies, as well as from limiting opportunities for smoking and raising the "costs" of smoking (eg, the inconvenience or discomfort associated with smoking outdoors). ${ }^{18}$

Norway's smoking ban was accompanied in the period immediately following the ban by a reduction in smoking among a national sample of food service workers and the reduction was maintained almost a year later. Results showed that between baseline measurement before the ban and four months post-implementation, there were significant declines in prevalence of daily smoking $(-3.6 \%$ points, $p<0.005)$, daily smoking at work (-6.2\% points, $p<0.001)$, number of cigarettes smoked by continuing smokers $(-1.55, p<0.001)$ and number of cigarettes smoked at work by continuing smokers (-1.63, $p<0.001) .{ }^{19}$

In the survey of the owners of 1641 hospitality premises from Italy $15 \%$ of owners who were smokers reported that they had quit after the smoking ban and $61 \%$ reported that they smoked fewer cigarettes per day. ${ }^{4}$

At the same time, smoking prevalence among Italian general population aged 15 and over decreased from 2004 to 2006 by $7.3 \%$, from $26.2 \%$ to $24.3 \%$. Moreover, after the ban of smoking in public places (in January-September 2005) total sales of nicotine replacement therapy (NRT) products increased by $10.8 \%$, above all in the first five months after the smoking ban. ${ }^{4}$

In Ireland, aproximately $46 \%$ of a national representative sample of smokers reported that the law had made them more likely to quit. Among Irish smokers who had quit at post-legislation, $80 \%$ reported that the law had helped them quit and $88 \%$ reported that the law helped them stay quit. ${ }^{12}$

\section{The health impact of comprehensive smoking ban}

Some of the most widespread health effects of SHS include respiratory illnesses among children and adults. Passive smokers in workplaces have reported more symptoms from the airways and more days lost from work due to chest colds than control subjects. ${ }^{2,8}$

On the other hand, exposure to SHS has been shown to increase the risk of fatal and nonfatal coronary heart disease (CHD) in nonsmokers by about 30\%. Growing evidence indicates that both active and passive smoking increase cardiac risk through both chronic (atherosclerosis) and acute (platelet activation, endothelial dysfunction) pathways. Laboratory findings indicate that even brief exposure to second hand smoke can cause platelet aggregation and other hemodynamic changes responsible for the development of ischaemic heart disease. ${ }^{20}$

In light of the health effects that result from exposure to SHS, several studies have assessed how banning 
smoking in public places can positively affect health outcomes related to exposure to SHS.

In Norway a study evaluated the effect of a total ban on smoking indoors in restaurants and other hospitality business premises on respiratory symptoms among workers in the industry. A significant decrease in respiratory symptoms (morning cough, daytime cough, phlegm cough, dyspnea and wheezing) among service industry workers was found five months after the enacting of the public smoking ban in Norway ${ }^{21}$. Another study from Norway shows a larger cross shift decrease in lung function of workers from 13 bar and restaurants from Oslo before compared with after the implementation of the ban. ${ }^{22}$

In Ireland, it was also noticed statistically significant improvements in measured pulmonary function tests and significant reductions in self-reported symptoms and exposure levels in nonsmoking barmen from 42 bars one year after the ban. ${ }^{8}$

In Italy, epidemiological studies have found that there is a decrease in risk of acute myocardial infarction (AMI) within some months after cessation of SHS exposure In the Piedmont region of Italy (4 million inhabitants) rates of admission for AMI before the ban (October-December 2004) and during the ban (February-June 2005) were analysed. Each period was compared with the corresponding period 12 months before. Among persons aged under 60, the number of admissions for AMI decreased significantly after the introduction of the ban: from 922 cases in February-June 2004 to 832 cases in February-June 2005 (sex- and ageadjusted rate ratio, $0.89 ; 95 \%$ confidence interval, 0.81 $0.98)$. No decrease was seen before the ban. No effect was found among persons aged at least 60 . The researchers estimated that the observed reduction in active smoking after the introduction of the ban could account for a $0.7 \%$ decrease in admissions for AMI during the study period, suggesting that most of the observed effect (11\%) might be due to the reduction of passive smoking. ${ }^{20}$

Another study from Italy analyzed acute coronary events (out-of-hospital deaths and hospital admissions) between 2000 and 2005 in residents from Rome 35 to 84 years of age. The researchers computed annual standardized rates and estimated rate ratios by comparing the data from prelegislation (2000-2004) and postlegislation (2005) periods. They took into account several time-related potential confounders, including particulate matter $\left(\mathrm{PM}_{10}\right)$ air pollution, temperature, influenza epidemics, time trends, and total hospitalization rates. The reduction in acute coronary events was statistically significant in 35 - to 64 -year-olds $(11.2 \%, 95 \%$ CI $6.9 \%$ to $15.3 \%)$ and in 65 - to 74 -year-olds $(7.9 \%, 95 \%$ CI $3.4 \%$ to $12.2 \%$ ) after the smoking ban. Moreover, the reduction tended to be greater in men and among lower socioeconomic groups. Again, no evidence was found of an effect among the very elderly. ${ }^{23}$

Authorities from Scotland also reported a 17\% reduction in heart attack admissions to nine Scottish hospitals in the first year after the ban came into force. This compares with an annual reduction in Scottish admissions for heart attack of $3 \%$ per year in the decade before the ban. ${ }^{24}$

\section{The economic impact of comprehensive smoking ban}

In addition to the morbidity and mortality associated with chronic exposure to secondhand smoke, there are also real and substantial economic costs. In the United States of America (USA) an analyze of the costs associated with involuntary exposure to SHS concluded that such exposure imposes significant costs on nonsmokers and society as a whole. Total annual costs for conditions with well-documented increases in morbidity were estimated at nearly $\$ 5$ billion in direct medical costs and nearly $\$ 5$ billion in indirect costs. ${ }^{18}$ Hence, the implementation of clean indoor laws can contribute to the decrease of economical costs associated with problems caused by exposure to secondhand smoke. In New York, for example, the implementation of a comprehensive smoking ban lead in 2004 to 3813 fewer hospital admissions for acute myocardial infarction than would have been expected in the absence of the comprehensive smoking ban, which meant a direct health care cost savings of $\$ 56$ million. ${ }^{25}$

Nevertheless, the spread of smoke-free air policies has been slowed in many parts of the world by concerns about the economicimpact of these policies, particularly on the hospitality industry. The tobacco industry has fueled this concerns with its claims that smoke-free air policies will result in declining restaurant, bar, and other hospitality industry revenues; lost jobs in the hospitality sector; and business closings. ${ }^{18}$

Despite of this, several studies from USA indicates that there is no negative economic impact of clean indoor air policies on the hospitality industry. ${ }^{18}$ In Europe, there are less high quality studies focusing on the economical impact of smoking ban in public places. Nevertheless, several data indicates that there is no major negative economic impact of clean indoor air policies on the hospitality industry, despite the fact that tobacco industry has attempted to create fears to the contrary.

In Ireland, a study performed among 38 public houses from Dublin prior to the introduction of the ban and one year later after the introduction of the ban, has shown that there was no significant decrease in the 
number of staff employed or in customer numbers; moreover, the number of customers increased by $11 \%$. It concluded that the ban has been good for the industry, staff, and customers. ${ }^{5}$

In Italy, after the introduction of the new policies, $9.6 \%$ of subjects of a national representative sample reported to go more frequently and $7.4 \%$ less frequently to cafes and restaurants.?

In Ireland volume sales of alcohol in Irish bars reached their peak in 2001 and had fallen by 15\% even before the smoke-free legislation came into force in March 2004. Data reported by the Central Statistics Office on retail sales showed that seasonally adjusted turnover in bars has fallen by around 3.8\% in value and $5.8 \%$ in volume during the first nine months the smokefree initiative has been in place and that the bar sales have climbed by $2.3 \%$ in both value and volume terms between September and November 2004. Economists have stated that this trend made the claim by the Vintners' Federation of Ireland that sales were down 25\% since the smoking ban was instituted "totally misleading". ${ }^{10}$

In Italy, a study assessed opinions of owners/managers from 50 restaurants. It showed that $24 \%$ of owners predicted major financial losses before the implementation of the law, but one year later, only 7\% reported major financial losses. Moreover, most owners/managers $(88 \%)$ reported positive attitudes about the law and $79 \%$ reported such attitudes among clients. ${ }^{6}$

The Italian Federation of Hospitality Industries reported a significant economic loss only for gambling and bingo houses after the implementation of the ban, but the precise amount of the loss was not reported. ${ }^{4}$

\section{Conclusions}

Many studies from Europe show that clean indoor air laws are well accepted by the public, lead to a significant decrease of exposure to second hand smoking in public places and have the potential to contribute to the reduction in overall cigarette consumption. Researches documented important short-term effects on the respiratory system health of workers from the bars and restaurants after the introduction of the law. Moreover, important short-term effects on the rates of hospital admission for acute myocardial infarction were observed. The vast majority of scientific evidence indicates that there is no negative economic impact of clean indoor air policies on the hospitality industry, despite the fact that tobacco industry has attempted to create fears to the contrary.

These findings recommend the implementation of comprehensive smoking ban laws as an important measure of health promotion. They support initiatives in many countries toward implementing smoke-free legislation, particularly those who have ratified the Framework Convention on Tobacco Control, which calls for legislation to reduce tobacco smoke pollution.

In order to help further progress in the diffusion of clean indoor air laws, continued documentation of their short term and long-term impact on public health as well of their economical consequences, particularly within the hospitality industry, are necessary.

\section{References}

I. California Environmental Protection Agency. Health Effects of Exposure to Environmental Tobacco Smoke-Final Report and Appendices. California: EPA, Office of Environmental Health Hazard Assessment, 1997.

2. Engelen M, Farrelly M, Hyland A. The Health and Economic Impact of New York's Clean Indoor Air Act. Albany, NY: New York State Department of Health, 2006.

3. European network for smoking prevention. European trends towards smoke-free provisions. . http://www.ensp.org/files/legislation_on_ smokefree_workplaces_200704.pdf. Accessed on March 2008. 4. Gorini G, Chellini E, Galeone D. What happened in Italy? A brief summary of studies conducted in Italy to evaluate the impact of the smoking ban. Ann Oncol 2007; I8(I0): 1620-1622.

5. McCaffrey M, Goodman PG, Kelleher K, Clancy L. Smoking, occupancy and staffing levels in a selection of Dublin pubs pre and post a national smoking ban, lessons for all. Ir J Med Sci 2006; 175:37-40.

6. Binkin N, Perra A, Aprile V, et al. Effects of a generalized ban on smoking in bar and restaurants, Italy. Int J Tubercul Lung Dis 2007; I I: 522-527.

7. Gallus S, Zuccaro P, Colombo P, et al. Effects of new smoking regulations in Italy. Ann Oncol 2006; 17: 346-347.

8. Goodman P, Agnew M, McCaffrey M, Paul G, Clancy L. Effects of the Irish Smoking Ban on Respiratory Health of Bar Workers and Air Quality in Dublin Pubs. Am J Resp Critical Care Medicine 2007; I75: 840-845.

9. Semple S, Maccalman L, Naji A, et al. Bar workers' exposure to secondhand smoke: the effect of Scottish smoke-free legislation on occupational exposure. Ann Occup Hyg 2007; 5 I (7):57I-580.

10. Howell F. Smoke-free bars in Ireland: a runaway success. Tob Control 2005; 14:73-74

I I. Pursell L, Allwright S, O'Donovan D, et al. Before and after study of bar workers' perceptions of the impact of smoke-free workplace legislation in the Republic of Ireland. BMC Public Health. 2007; 7(147):I3I

I2. Fong GT, Hyland A, Borland R, et al. Reductions in tobacco smoke pollution and increases in support for smoke-free public places following the implementation of comprehensive smoke-free workplace legislation in the Republic of Ireland: findings from the ITC Ireland/UK Survey. Tob Control 2006; Suppl 3:51-58.

13. Hilton S, Semple S, Miller BG, et al. Expectations and changing attitudes of bar workers before and after the implementation of smoke-free legislation in Scotland. BMC Public Health 2007, 7:206.

I4. Semple S, Creely KS, Naji A, Miller BG, Ayres JG. Secondhand smoke levels in Scottish pubs: the effect of smoke-free legislation. Tob Control 2007; 16(2): I27-132.

I5. Haw SJ, Gruer L. Changes in exposure of adult non-smokers to secondhand smoke after implementation of smoke-free legislation in Scotland: national cross sectional survey. BMJ 2007;335:549.

16. Akhtar PC, Currie DB, Currie CE, Haw SJ. Changes in child exposure to environmental tobacco smoke (CHETS) study after implementation of smoke-free legislation in Scotland: national cross sectional survey. BMJ 
2007;335:545.

17. Valente P, Forastieri F, Bacosi A, et al. Exposure to fine and ultrafine particles from secondhand smoke in public places before and after the smoking ban, Italy 2005. Tob Control 2007; 16:3 |2-3I7.

18. Eriksen M, Chaloupka F. The Economic Impact of Clean Indoor Air Laws. CA Cancer J Clin 2007; 57:367-378

19. Braverman MT, Aarø LE, Hetland J. Changes in smoking among restaurant and bar employees following Norway's comprehensive smoking ban. Health Prom Int 2008; 23(I):5-15.

20. Barone-Adesi F, Vizzini L, Merletti F et al. Short-term effects of Italian smoking

regulation on rates of hospital admission for acute myocardial infarction. Eur Heart J 2006; 27: 2468-2472.

21. Eagan TM, Hetland J, Aarø LE. Decline in respiratory symptoms in service workers five months after a public smoking ban. Tob Control
2006; 15(3):242-246.

22. Skogstad M, Kjærheim K, Fladseth G, et al. Cross shift changes in lung function among bar and restaurant workers before and after implementation of a smoking ban. Occup Environ Med 2006; 63:482-487 23. Cesaroni G, Forastiere F, Agabiti N, et al. Effect of the Italian Smoking Ban on Population Rates of Acute Coronary Events. Circulation 2008; I77(9): I | 183-1 I88.

24. The Scottish Government. Smoking ban brings positive results-Press release. http://www.scotland.gov.uk/News/Releases/2007/09//008/400. Accessed on March 2008.

25. Juster HR, Loomis BR, Hinman TM, et al. Declines in Hospital Admissions for Acute Myocardial Infarction in New York State After Implementation of a Comprehensive Smoking Ban. Am J Pub Health 2007; 97 (II):2035-2039. 